\title{
IDENTIFIKASI ISOLAT BAKTERI TERMOFILIK DARI SUMBER AIR PANAS LEJJA, KABUPATEN SOPPENG
}

\author{
${ }^{1}$ Rafiah Mahmudah, ${ }^{2}$ Maswati Baharuddin, ${ }^{2}$ Sappewali, \\ Jurusan Kimia, Fakultas Sains dan Teknologi, UIN Alauddin Makassar \\ Email: rafiah.mahmudah88@gmail.com
}

\begin{abstract}
Identification of bacterial isolates local termofilik at hot springs is the first step of a series of studies of the exploration and utilization of indigenous bacteria an area. This research aims to know the bacterial isolate bacteria from the genus termofilik in the hot springs at Soppeng Lejja and know the optimum incubation time and temperature on the growth of bacterial isolates termofilik from hot springs, Soppeng Regency Lejja. The methods used in the study include the creation of media, rejuvenation, the identification of isolates of bacteria. Bacterial identification to genus level based on Bergey's Manual of Determinative Bacteriology are done with different test, namely: gram staining test, oxidation test, fermentation test, carbohydrates test, SIM test, TSIA test, $\mathrm{Mr} / \mathrm{Vp}$ test, citrat test and urea test. The results showed that bacterial isolates identified as termofilik in the genus Pseudomonas sp, which is a gram-negative, rod-shaped cells against oxidation test, positive, negative and red metyl test against a test fermentation. indol, motility, citrate, urea and the production of $\mathrm{H}_{2} \mathrm{~S}$.
\end{abstract}

Keywords: hot springs, termofilik bacteria, Pseudomonas sp.

\section{PENDAHULUAN}

Indonesia merupakan negara kepulauan yang beriklim tropis yang memiliki banyak daerah pegunungan berapi dengan aktivitas vulkanik yang tinggi, sehingga banyak ditemukan lokasi sumber daya panas bumi yang tersebar di seluruh kepulauan Indonesia. Salah satu satu sumber panas bumi di Sulawesi selatan berupa mata air panas. Mata air panas dapat ditemukan dengan mudah di kabupaten Soppeng yaitu mata air panas Lejja yang telah menjadi objek pariwisata andalan di daerah tersebut.

Salah satu manfaat yang dihasilkan dari sumber mata air panas adalah isolasi bakteri termofilik. Bakteri termofilik adalah mikroorganisme yang mampu hidup pada suhu $45-80^{\circ} \mathrm{C}$. Dalam banyak kasus mikroorganisme termofilik tidak hanya beradaptasi terhadap kondisi ekstrim tetapi juga membutuhkan kondisi ini untuk berproduksi.

Bakteri termofilik isolat lokal dari berbagai mata air panas di Indonesia telah berhasil diisolasi, dikarakterisasi dan di uji potensi enzimatis yang dimilikinya. Mikroorganisme yang berhasil diisolasi di Indonesia antara lain bakteri termofil sumber mata air panas di Pacet (8 genus bakteri antara lain Thermus sp, Acetogenium sp, Bacillus sp, Thermotrix sp, Thermodesulfo bacterium sp, Thermomicobrium sp, Pseudomonas sp dan Sulfobacillus sp) (Asnawi, 2006). Sumber mata air panas di songgogirti telah dilakukan oleh Karina Buditianingsih pada tahun 2011 yang berhasil mengidentifikasi 2 genus bakteri yaitu 
Pseudomonas sp dan Vibrio sp. dan Maria yuli endah pada tahun 2012 mengidentifikasi 2 genus yaitu Bacillus sp dan Vibrio sp.

Sumber panas bumi di Kabupaten Soppeng berupa mata air panas Lejja yang ditemukan di kawasan hutan lindung berbukit Desa Bulu, Kecamatan Marioriawa, 44 km utara Kota Watansoppeng yang merupakan ibu kota Kabupaten Soppeng. Mata air panas Lejja bertipe bikarbonat yang kaya akan mineral dan suhunya mencapai $60^{\circ} \mathrm{C}$ dengan kandungan sulfur mencapai $1,5 \%$. Kondisi ini berpeluang untuk memperoleh bakteri termofilik terutama bakteri selulolitik yang dapat diidentifikasi genus serta mengetahui optimalisasi pertumbuhan bakterinya. Mata air panas Lejja selama ini hanya dimanfaatkan sebagai objek pariwisata pemandian air panas saja. Mengingat manfaat bakteri termofilik sebagai penghasil enzim termostabil, maka diperlukan penelitian mengenai bakteri termofilik.

Penelitian bakteri termofilik dari sumber air panas Lejja sebelumnya telah dilakukan oleh Hafsah (2007), yang berhasil mengidentifikasi 3 genus bakteri penghasil protease yaitu Bacillus licheniformis, Bacillus stearoformis dan Bacillus coagulans. Penelitian bakteri termofilik penghasil enzim selulase dari sumber mata air panas Lejja juga telah dilakukan oleh Fitri (2012) yang berhasil mengisolasi bakteri termofilik dan memproduksi enzim selulase dengan waktu produksi optimum 48 jam dengan nilai aktivitas $3.4413 \times 10^{-3} \mathrm{U} / \mathrm{mL}$.

Identifikasi bakteri merupakan langkah awal dari rangkaian penelitian eksplorasi dan pemanfatan bakteri indigenous suatu daerah. Identifikasi dapat dilakukan secara konvensional melalui karakterisasi biokimia dan mikroskopis sel bakteri, hingga berbasi molekuler. Pada penelitian selanjutnya akan dilakukan identifikasi genus dan optimalisasi pertumbuhan bakteri. Eksplorasi dan identifikasi bakteri termofilik penghasil selulase dapat digunakan sebagai salah satu cara untuk mengenalkan potensi dan keragaman bakteri termofilik dari sumber air panas di wilayah Indonesia. Selain itu, dapat menambah koleksi bakteri termofilik penghasil selulase yang berasal dari isolat lokal.

Penentuan genus isolat bakteri ditentukan sesuai dengan Bergey's Manual of Determinative Bacteriology disertai pengamatan mikroskopis melalui beberapa uji yakni uji biokimia dan uji morfologi. Beberapa sifat bakteri yang digunakan untuk identifikasi ini mencakup morfologi koloni (ukuran, bentuk, warna) morfologi mikroskopik serta kebutuhan biokimia dan pembiakannya (kemampuannya mengubah zat gula tertentu, jenis produksi akhir yang dihasilkan dari fermentasi, kebutuhan zat asam, dan masih banyak lagi tergantung kepada jenis bakteri yang diidentifikasi). Optimalisasi pertumbuhan isolat bakteri dilakukan dengan menetukan suhu optimum, waktu inkubasi dan variasi media yang digunakan dalam proses pertumbuhan bakteri.

Berdasarkan uraian di atas, maka dilakukan penelitian identifikasi bakteri termofilik yang berasal dari sumber air panas Lejja, Kabupaten Soppeng dengan mengunakan Bergey's Manual of Determinative Bacteriology melalui uji morfologi (pewarnaan gram) dan uji biokimia (uji oksidase, uji motilitas, uji Mr/VP, uji nitrat, produksi indol dan uji gula). Sedangkan optimalisasi pertumbuhan isolat bakteri dengan menetukan suhu optimum dan waktu inkubasi. 


\section{Tujuan Penelitian}

Tujuan penelitian ini untuk mengetahui genus bakteri dari isolat bakteri termofilik pada sumber air panas Lejja di Soppeng dan mengetahui suhu dan waktu inkubasi optimum pada pertumbuhan isolat bakteri termofilik dari sumber air panas Lejja, Kabupaten Soppeng.

\section{METODE PENELITIAN Waktu dan Tempat Penelitian}

Penelitian ini dilaksanakan pada bulan April sampai Juni 2014 di Laboratorium Biokimia Fakultas Sains dan Teknologi UIN Alauddin Makassar dan Laboratorium Mikrobiologi Fakultas Kedokteran UNHAS.

\section{Alat}

Alat-alat yang digunakan dalam penelitian ini yaitu Spektrofotometer UV-Vis (Cory Conc 50), inkubator (Heraeus), Autoklaf (Astell), oven (Memmert), laminar air flow (Esco), neraca analitik (Kern), mikroskop, $\mathrm{pH}$ meter digital, lemari pendingin, penangas listrik, mikropipet, termometer $100^{\circ} \mathrm{C}$, cawan petri, pembakar bunsen, sendok tanduk, jarum ose, botol semprot, botol sampel steril dan alat-alat gelas yang umum dipakai di laboratorium.

\section{Bahan}

Bahan yang digunakan dalam penelitian ini adalah alkohol 70\%, aluminium foil, aquadest steril, bakto agar, cotton bud steril, isolat air panas Lejja, kalium hidropospat $\left(\mathrm{K}_{2} \mathrm{HPO}_{4}\right)$, kalium nitrat $\left(\mathrm{KNO}_{3}\right)$, karboksimetil selulase $(\mathrm{CMC})$, magnesium sulfat $\left(\mathrm{MgSO}_{4}\right)$, magenesium sulfat heptahidrat $\left(\mathrm{MgSO}_{4} \cdot 7 \mathrm{H}_{2} \mathrm{O}\right)$, media selektif selulolitik, natrium klorida $(\mathrm{NaCl})$, reagen alpha naphtol 5\%, reagen kovac's, reagen methyl red dan yeast ekstrak.

\section{Prosedur Kerja \\ Media Selektif Selulolitik}

Komposisi dari media terdiri dari 0,15 gram $\mathrm{KNO}_{3}, 0,04$ gram $\mathrm{MgSO}_{4}, 0,1$ gram $\mathrm{K}_{2} \mathrm{HPO}_{4}$ , $\mathrm{CaCl}_{2}$ 0,004 gram, 0,4 gram yeast ekstrak, bakto agar 2,5 gram dan 2 gram CMC. Semua bahan dimasukkan dalam beaker gelas $250 \mathrm{~mL}$ dan dicampur dengan aquades sebanyak $100 \mathrm{~mL}$, dipanaskan sampai mendidih sambil diaduk hingga larut, kemudian media tersebut dimasukkan ke dalam enlenmeyer dan ditutup kapas, kemudian disterilisasi dalam autoklaf menggunakan suhu $121^{\circ} \mathrm{C}$ dan tekanan 1 atm selama 15 menit (Dyah Ayu Saropah, 2012).

\section{Pembuatan Media CMC Cair}


Media yang digunakan adalah media $\mathrm{CMC}$ yang terdiri dari 1 gr $\mathrm{CMC} ; 0,04$ gr $\mathrm{MgSO}_{4} .7 \mathrm{H}_{2} \mathrm{O} ; 0,15$ gr $\mathrm{KNO}_{3} ; 0,1$ gr $\mathrm{K}_{2} \mathrm{HPO}_{4} ; 0,004$ gr $\mathrm{CaCl}_{2} \cdot 2 \mathrm{H}_{2} \mathrm{O}$ dan 0,4 gr yeast extract. Semua bahan dimasukkan dalam beaker gelas $250 \mathrm{ml}$ dan dicampur dengan aquades sebanyak $100 \mathrm{~mL}$, dipanaskan sampai mendidih sambil diaduk hingga larut, kemudian media tersebut dimasukkan ke dalam enlenmeyer dan ditutup kapas, kemudian disterilisasi dalam autoklaf menggunakan suhu $121{ }^{\circ} \mathrm{C}$ dan tekanan $1 \mathrm{~atm}$ selama 15 menit (Dyah, 2012).

\section{Identifikasi Isolat Bakteri}

Uji pewarnaan gram

Prosedur yang digunakan adalah isolat bakteri diambil 1 ose dan digores-goreskan pada permukaan preparat steril kemudian dilakukan fiksasi. 1 tetes kristal violet ditambahkan ke permukaan preparat yang terdapat lapisan bakteri tersebut dan didiamkan selama 3 menit. Setelah 1 menit, preparat dibilas dengan air sampai zat warna luntur. Preparat dikeringkan di atas api spiritus. Setelah kering, 1 tetes larutan lugol ditambahkan ke permukaan preparat dan didiamkan selama 1 menit. Setelah 1 menit, preparat dibilas dengan air. Preparat dibilas dengan alkohol 96\% sampai semua zat warna luntur kemudian dicuci dengan air. Preparat dikeringkan di atas api spiritus. Setelah kering, 1 tetes fuchsin alkali ditambahkan ke permukaan preparat dan didiamkan selama 45 detik. Preparat dicuci dengan air dan dikeringkan. preparat ditambahkan emerci oil. Preparat diamati menggunakan mikroskop dengan perbesaran 1000x.

\section{Uji Produksi $\mathrm{H}_{2} \mathrm{~S}$ dan Gas}

Isolat bakteri termofilik dinokulasikan secara aseptis ke medium Triple Iron Sugar Agar (TSIA) dengan jarum inokulasi yang ujungnya tajam yang telah mengandung isolat bakteri. Selanjutnya, diinkubasi selama 24-48 jam. Uji positif produksi $\mathrm{H}_{2} \mathrm{~S}$ ditandai dengan terbentuknya warna hitam pada medium. Uji positif pembentukan gas ditandai dengan terbentuknya gas di dasar medium, sehingga medium naik ke atas.

\section{a. Uji SIM}

Satu ose isolat bakteri diinokulasikan secara aseptis ke $3 \mathrm{ml}$ medium SIM dalam tabung reaksi. Kemudian diinkunbasi selama 24 jam pada suhu $37^{\circ} \mathrm{C}$. Untuk uji indol ditambahkan dengan Kovacs reagent. Hasil uji positif ditandai dengan terbentuknya warna merah dan untuk uji motilitas ditandai dengan media menjadi keruh karena adanya pergerakan dari isolat.

\section{b. Uji Mr/VP (methyl red)}

Biakan bakteri dari media CMC diinokulasi pada media Mr/Vp dan diinkubasi selama 24 jam pada suhu $37^{\circ} \mathrm{C}$. Pertumbuhan bakteri pada biakan $\mathrm{Mr} / \mathrm{Vp}$ selanjutnya dibagi ke dalam 2 tabung. Untuk uji Mr ditetesi dengan 2-3 tetes reagen methyl red dan uji $\mathrm{Vp}$ tabung ditetesi dengan 2-3 tetes reagen alpha naphtol $5 \%$. 
c. Uji sitrat

Koloni bakteri pada media CMC diambil dengan ose dan diinokulasi pada media sitrat, selanjutnya diinkubasi pada suhu $37^{\circ} \mathrm{C}$ selama 24 jam. Bakteri yang memanfaatkan sitrat sebagai sumber karbon akan menghasilkan natrium karbonat yang bersifat alkali, sehingga dengan adanya indikator brom thymol blue menyebabkan warna biru pada media (Suyati, 2010).

\section{d. Uji oksidasi}

Reagen oksidasi dituang ke kertas saring. Isolat bakteri diambil dan digoreskan ke kertas saring tersebut. Pengambilan isolat bakteri tidak boleh menggunakan alat yang berasal dari logam (harus dari kayu atau plastik). Reaksi ditunggu selama 30 detik. Hasil positif ditandai dengan munculnya warna ungu, sedangkan hasil negatif ditandai dengan munculnya warna merah muda.

e. Uji Fermentasi karbohirdat

Isolat bakteri diambil 1 ose dan dimasukkan ke dalam media kaldu karbohidrat glukosa, sukrosa, laktosa dan mannitol yang mengandung brom cresol purple (BSP) dan Phenol red sebagai indicator $\mathrm{pH}$. Media yang telah berisi isolat, diinkubasi selama 2 hari. Perubahan warna yang terjadi diamati. Warna merah mengindikasikan tidak adanya asam, sedangkan warna kuning mengindikasikan adanya asam.

\section{f. Uji urea}

Isolat bakteri termofilik diinokulasi pada media agar urea (agar miring) dan di inkubasi pada suhu $37^{\circ} \mathrm{C}$ selama 48 jam. Perubahan warna yang terjadi diamati. warna merah-ungu pada media mengidikasikan bakteri memberikan reaksi positif.

\section{HASIL DAN PEMBAHASAN}

\section{Identifikasi bakteri}

Penentuan genus dari isolat bakteri selulolitik termofilik dilakukan melalui beberapa tahap, yakni: peremajaan isolat, penyuburan isolat, pewarnaan gram dan uji bikomia berupa uji oksidasi, uji fermentasi karbohidrat, uji TSIA, uji SIM, uji Mr/VP, uji sitrat dan uji urea.

\section{Peremajaan Bakteri Termofilik}

Sebelum melakukan identifikasi, bakteri terlebih dahulu diremajakan. Peremajaan isolat bakteri termofilik dilakukan pada media CMC sebelum mengidentifikasi isolat bakteri termofilik. Peremajaan bertujuan untuk meregenerasi sel bakteri, menjaga ketersediaan nutrisi dan untuk menghindari adanya perubahan karakteristik dari kultur murni yang ditanam. Selain 
itu, peremajaan bertujuan mengaktivasi dan mempersiapkan sel pada fase eksponensial. Hal ini dapat mempercepat fase adaptasi pada saat proses isolasi.

\section{Pewarnaan Gram}

Pewarnaan gram merupakan langkah awal untuk identifikasi bakteri. Pada pewarnaan gram bertujuan untuk mengetahui sifat gram serta morfologi dari bakteri yang diidentifikasi. Bakteri akan dikelompokkan menjadi dua kelompok, yaitu bakteri gram positif dan bakteri gram negatif. Pada pewarnaan Gram, hasil yang didapat akan ditentukan dari komposisi dinding sel pada bakteri. Pada pewarnaan Gram, reagen yang digunakan terdiri 4 jenis, yaitu kristal violet, iodin, alkohol dan fuchsin alkali.

Pewarnaan gram didasarkan pada perbedaan struktur dinding sel bakteri, sehingga menyebabkan perbedaan reaksi dalam permeabilitas zat warna dan penambahan larutan pencuci. Dinding sel bakteri Gram positif terdiri dari lapisan peptidoglikan yang tebal sedangkan dinding sel bakteri Gram negatif mempunyai kandungan lipid yang tebal. Ketika ditambahkan pewarnaan kristal violet maka dinding sel bakteri Gram positif maupun Gram negatif akan menyerap zat warna tersebut namun ketika diberi alkohol, kristal violet pada Gram negatif akan luntur disebabkan struktur dinding selnya yang sebagian besar tersususun oleh lipid, sehingga ketika diberi fuchsin alkali (zat warna kedua) dinding sel bakteri gram negatif akan menyerapnya kembali sehingga hasil pewarnaan bakteri Gram negatif akan berwarna merah, sedangkan bakteri gram positif akan tetap berwarna ungu walaupun diberi zat warna kedua, karena dinding selnya tersusun oleh lapisan peptidoglikan yang tebal sehingga tidak dapat dicuci oleh alkohol.

Berdasarkan hasil penelitian isolat bakteri menunjukkan warna merah pada hasil mikroskopis. warna merah ini mengindikasikan bahwa isolat bakteri termasuk kelompok bakteri Gram negatif. selain itu isolat bakteri merupakan koloni tunggal dengan bentuk sel batang (Bacillus). Untuk memmberikan hasil optimal pada pewarnaan Gram sebaiknya menggunakan biakan segar yang berumur $24-48$ jam, karena pada biakan tua banyak sel yang mengalami kerusakan pada dinding selnya, hal ini mengakibatkan keluarnya zat warna ketika dicuci dengan larutan pemucat, sehingga menyamarkan hasil.

Penemuan isolat Gram negatif pada sumber air panas Lejja, dapat dihubungkan dengan kondisi lingkungan. Bakteri Gram negatif memerlukan nutrisi yang relatif lebih sederhana dibandingkan dengan bakteri Gram positif. Hal ini berarti kemampuan kelompok bakteri ini untuk tumbuh pada suatu lingkungan lebih besar dibandingkan bakteri Gram positif.

\section{Uji Oksidasi}

Setelah mengetahui Gram dari isolat bakteri maka dilakukan uji oksidasi untuk isolat bakteri Gram negatif. Uji oksidasi dilakukan untuk mendapatkan genus yang lebih spesifik dari isolat bakteri tersebut.

Berdasarkan hasil penelitian, isolat bakteri menunjukkan hasil positif, yang ditandai dengan munculnya warna ungu pada permukaan kertas saring. Hal ini berarti bahwa isolat 
termasuk kelompok bakteri yang mempunyai enzim sitokrom oksidase. Enzim sitokrom oksidase merupakan enzim kompleks yang berperan dalam fosforilasi oksidatif. Menurut second edition of Bergeys Manual bakteri yang menghasilkan oksidase sitokrom, yaitu pseudomonas sp., vibrio sp., dan Aeromonas sp. Bakteri oksidase-positif memungkinkan bakteri tersebut untuk mengoksidase reagen yang mengandung amina tertentu.

\section{Uji Fermentasi Glukosa}

Berdasarkan hasil penelitian media fermentasi dari isolat menunjukkan warna merah setelah inkubasi selama 2 hari. Warna merah mengindikasikan bahwa isolat tidak menghasilkan asam pada fermentasi glukosa. Menurut second edition of Bergeys Manual, kelompok bakteri Gram negatif yang tidak menghasilkan asam dalam proses fermentasi gula sederhana (glukosa) hanya berasal dari Pseudomonas sp. Informasi lain yang diperoleh menunjukkan bahwa Pseudomonas sp. memiliki kharakteristik positif pada uji oksidasi, bakteri Gram negatif berbentuk batang lurus atau keriting dan tidak menghasilkan gas dan asam pada proses fermentasi gula sederhana. Semua informasi yang diperoleh sesuai dengan sifat yang dimiliki oleh isolat sehingga dapat disimpulkan bahwa isolat berasal dari Pseudomonas sp.

\section{Uji Hidrogen Sulfida}

Berdasarkan hasil penelitian pada media TSIA, reaksi yang dapat terlihat pada media TSIA yaitu pada seluruh bagian media, bagian slant dan butt memberikan hasil warna merah yang menujukkan bahwa media bersifat basa (Alkali) yang berati isolat bakteri tidak menghasilkan desulfurase sewaktu dibiakkan dalam media yang kaya akan asam amino yang mengandung sulfur yang akan membentuk $\mathrm{H}_{2} \mathrm{~S}$ yang bereaksi dengan $\mathrm{Fe}^{2+}$ pada media biakan menghasilkan FeS yang berwarna hitam dan tidak larut dalam air. Reaksi yang terjadi pada pembentukan $\mathrm{H}_{2} \mathrm{~S}$ adalah:

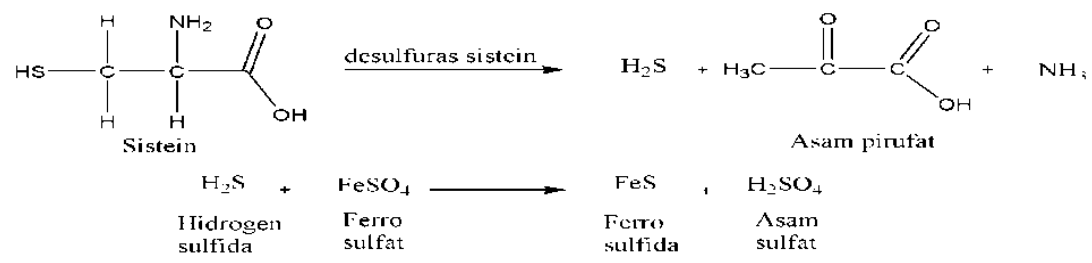

Gambar 1. Uji Hidrogen Sulfida

\section{Uji SIM}

Bakteri dari genus Pseudomonas sp. pada medium SIM menunjukkan hasil negatif. Uji SIM merupakan uji yang menggunakan media untuk membedakan tiga parameter yaitu Reduksi Sulfur untuk membedakan bakteri enterik, Uji Indol untuk bagian dari uji IMViC, untuk membedakan family Enterobacteriaceae dan Uji Motilitas untuk membedakan jenis bakteri secara umum. 
Pada reduksi sulfur, isolat bakteri tidak mengalami perubahan. Menurut teori Bakteri yang dapat mereduksi sulfur menjadi hydrogen sulfide, maka hydrogen sulfide akan bereaksi dengan zat besi ( Iron) menjadi ferric sulfide yang mengendap berwana hitam.

Uji indol pada isolat bakteri menunjukkan hasil negative, bakteri yang menghasilkan reaksi positif pada penambahan reagen Kovac yang mengandung $\mathrm{HCl}, \mathrm{n}$ - amyl alcohol dan pdimethylaminobenzaldehyde (DMABA) kedalam medium SIM, maka DMABA akan bereaksi dengan indol, menghasilkan senyawa Quinoidal merah. Reaksi pada uji indol adalah sebagai berikut:

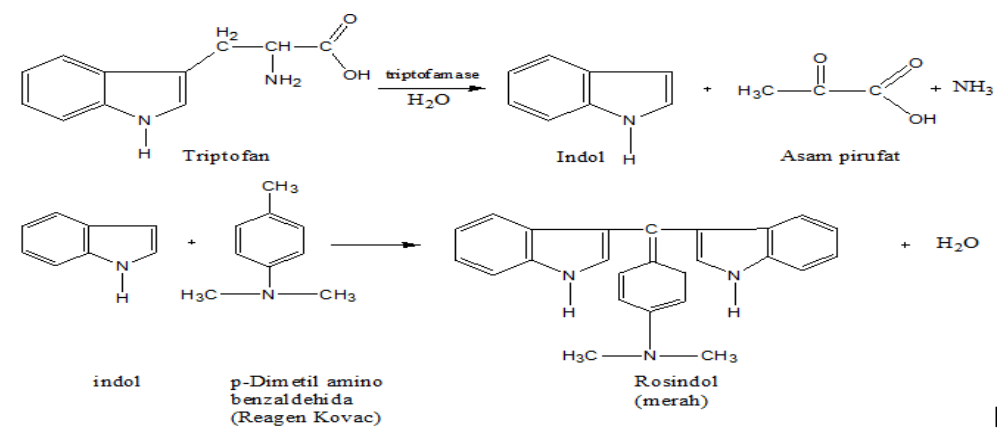

Gambar 2. Hidrolisis Triptofan dan Uji Indol

Uji motilitas pada isolat bakteri menunjukkan hasil negatif. Menurut Volk (1988) kemampuan suatu organisme untuk bergerak sendiri disebut motilitas. Hampir semua sel bakteri spiral dan sebagian dari sel bakteri basil bersifat motil, sedangkan bakteri yang berbentuk kokus bersifat immotil. Sifat ini diakibatkan oleh adanya alat motor cambuk yang disebut flagela sehingga sel bakteri dapat berenang di dalam lingkungan air. Motilitas sebagian besar jenis bakteri motil pada suhu relatif rendah $15-25^{\circ} \mathrm{C}$ dan mungkin tidak motil pada suhu $37^{\circ} \mathrm{C}$. Beberapa bakteri dapat melakukan gerakan meluncur yang sangat mulus yang hanya terjadi kalau persentuhan dengan benda padat. Kebanyakan bakteri yang motil dapat mendekati atau menjauhi berbagai senyawa kimia yang disebut kemotaksis (Taringan 1988).

$U j i M R / V P$

Uji methyl Red pada isolat bakteri menunjukkan hasil positif. Hal ini ditunjukkan dengan perubahan media MR dari kuning berubah setelah diinkubasi selama 48 jam dan penambahan methyl red menjadi warna merah.

Berdasarkan hasil penelitian diketahui bahwa isolat bakteri memiliki fermentasi asam campuran. Beberapa bakteri memfermentasikan glukosa dan menghasilkan berbagai produk yang bersifat asam sehingga akan menurunkan $\mathrm{pH}$ media pertumbuhannya menjadi 5.0 atau lebih rendah. Penambahan indikator $\mathrm{pH}$ methyl red dapat menunjukkan adanya perubahan $\mathrm{pH}$ menjadi asam. Methyl red berwarna merah pada lingkungan dengan $\mathrm{pH} 4.4$ dan berwarna kuning dalam lingkungan $\mathrm{pH}$ 6.2.

Uji VP menunjukkan hasil negatif. Berdasarkan hasil penelitian, isolat bakteri pada media VP yang telah diinkubasi selama 48 jam ditambahkan 40\% KOH dan 5\% alphanaphtol Al-Kimia | Volume 4 Nomor 12016 || 38 
memberikan hasil yang sama pada media yaitu warna kuning. Hal ini karena isolat bakteri tidak terdapat 2,3-butanadiol. Bila bakteri memfermentasikan karbohidrat menjadi 2,3-butanadiol sebagai produk utama, akan terjadi penumpukan bahan tersebut pada media pertumbuhan. Penambahan $40 \% \mathrm{KOH}$ dan $5 \%$ larutan alphanapthol dalam etanol dapat menentukan adanya asetilmetilkarbonil, yang berupa senyawa pemuka dalam sintesis 2,3-butanadiol. Pada penambahan $40 \% \mathrm{KOH}$, adanya asetoin ditunjukan oleh perubahan warna kaldu menjadi merah muda. Perubahan warna kaldu biakan lebih jelas pada bagian yang berhubungan dengan udara, karena sebagian 2,3-butanadiol dioksidasikan kembali menjadi asetoin sehingga memperjelas hasil reaksi.

\section{Uji sitrat}

Uji sitrat pada isolat bakteri memberikan hasil negatif berupa warna media yang tidak mengalami perubahan yaitu warna hijau. Uji sitrat digunakan untuk melihat kemampuan mikroorganisme menggunakan sitrat sebagai satu-satunya sumber karbon dan energi. Pada penelitian ini, digunakan medium Simmon's citrate agar yang merupakan medium sintetik dengan trinatrium sitrat sebagai satu-satunya sumber karbon, amonium $\left(\mathrm{NH}_{4}{ }^{+}\right)$sebagai sumber nitrogen dan brom timol biru sebagai indikator $\mathrm{pH}$. Bila mikroorganisme mampu menggunakan sitrat, maka asam akan dihilangkan dari medium biakan, sehingga menyebabkan peningkatan $\mathrm{pH}$ dan mengubah warna medium dari hijau menjadi biru. Perubahan warna dari hijau menjadi biru menunjukkan bahwa mikroorganisme mampu menggunakan sitrat sebagai satu-satunya sumber karbon.

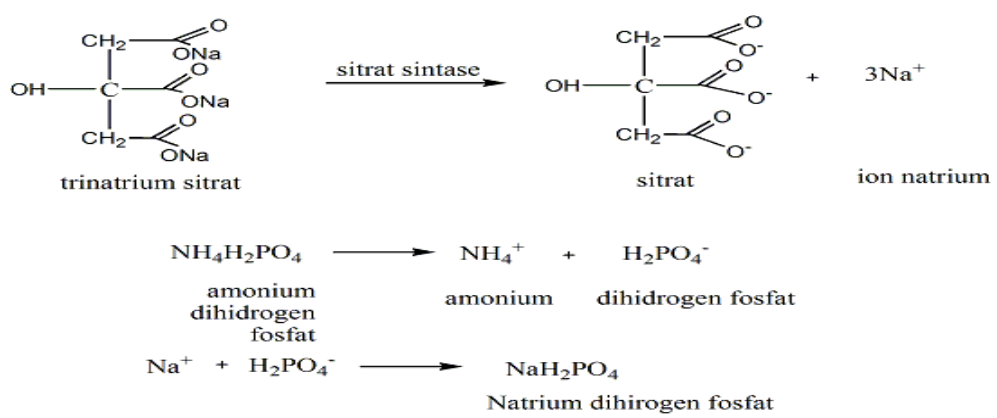

Gambar 3. Penggunaan Sitrat oleh Bakteri.

\section{Uji Urea}

Uji urea pada isolat bakteri memberikan hasil negatif berupa warna media yang tidak berubah yaitu merah-jingga, hal ini karena pada isolat bakteri tidak menghasilkan enzim urease. Mikroorganisme yang menghasilkan enzim urease akan mengurai urea menjadi ammonium dan $\mathrm{CO}_{2}$. Bila urea dihidrolisis, maka media biakan yang mengandung urea dan indicator $\mathrm{pH}$ (phenol red) akan mengakumulasikan ammonium dalam media biakan dan menyebabkan $\mathrm{pH}$ menjadi basa. Perubahan warna dari merah-jingga menjadi merah ungu merupakan petunjuk terjadinya hidrolisis urea. 


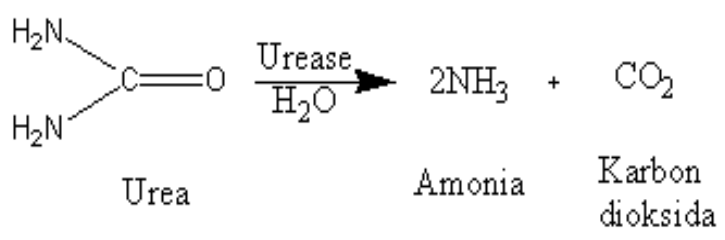

Gambar 4. Reaksi Hidrolisis Urea

\section{PENUTUP}

Kesimpulan

Berdasarkan hasil penelitian dapat disimpulkan bahwa isolat bakteri termofilik berasal dari genus Pseuodomonas sp. dengan karakteristik bakteri gramnegatif, sel berbentuk batang, positif terhadap uji oksidase dan positif terhadap uji metyl red.

\section{Saran}

Saran pada penelitian ini adalah sebaiknya penelitian lanjutan terhadap identifikasi bakteri perlu dilakukan untuk mengetahui spesies dari isolat bakteri bakteri dan Sebaiknya dilakukan optimalisasi pertumbuhan pada isolat bakteri.

\section{DAFTAR PUSTAKA}

Ayu, Dyah Saropah, et.all. "Kinetika Reaksi Enzimatis Ekstrak Kasar Enzim Selulase Bakteri Selulolitik Hasil Isolasi dari Bekatul". Alchemy vol 2, no. 1 (2012):

Buditianingsih, Karina, et.all. "Isolasi Bakteri Termofilik Dari Sumber Air Panas Di Songgoriti". Prosiding Tugas Akhir Semester Genap. (2011).

Christina, Dessy Sianturi. "Isolasi Bakteri dan Uji Aktivitas Amilase Termofil Kasar Dari Sumber Air Panas Penen Sibirubiru Sumatera Utara". Tesis (Medan: Sekolah Pascasarjana Universitas Sumatera Utara).

Departemen Agama Republik Indonesia. Al-Qur'an dan Terjemahnya. Jakarta: Depag, 2002.

Fikrinda. "Isolasi dan Karakterisasi Bakteri Penghasil Selulase Ekstremofilik dari Ekosistem Air Hitam”. Tesis.Bogor: IPB. 2000.

Ginting, Jusuf. "Isolasi Bakteri dan Uji Aktivitas Enzim Amilase Kasar Termofilik dari Sumber Air Panas Semangat Gunung Kabupaten Karo Sumatera Utara". Tesis.Medan: USU. 2009.

Hartanti. "Isolasi dan Seleksi Bakteri Selulolitik Termofilik dari Kawah Air Panas Gunung Pancar, Bogor".

Haryani, Y.,et,all. "Fermentasi Karbohidrat Oleh Isolat Salmonella spp. dari Jajanan Pinggir Jalan". Jurnal Indo Chemistry Acta 3, no. 1 (November, 2012): h. 
Irianto, Koes. Mikrobiologi: Menguak Dunia Mikroorganisme. Bandung: Yrama Widya, 2006.Hafsah. "Pengaruh Suhu Dan Ph Terhadap Aktivitas Protease Bakteri Termofilikdari Sumber Air Panas Lejja Kabupaten Soppeng Sulawesi Selatan Sebagai Sumber Belajar Mikrobiologi”. Tesis. Malang: Universitas Negeri Malang. 2007.

Kismiyati, et.all. "Isolation And Identification Gram Negative Bacteria At Lessions Of Gold Fish (Carassius auratus) By Infestation Ectoparasite Argulus sp". Jurnal Ilmiah Perikanan dan Kelautan vol. 1 no. 2 (November, 2009):

Locke, Thomas. et,all. Mikcrobiology and Infectioous Diseases on the move, terj. Rizqi Akbarani. Jakarta: Indeks, 2013.

M, H. Subandi. Mikrobiologi: Perkembangan, Kajian dan Pengamatan dalam Perspektif Islam. Bandung: Remaja Rosdakarya, 2010.

Maranatha, Betsy. "Aktivitas Enzim Selulase Isolat Asal Indonesia pada Berbagai Substrat Limbah Pertanian". Skripsi. Bogor: Fak. Matematika dan Ilmu Pengetahuan Alam IPB, 2008.

Maria dan Surya. "Isolasi dan Identifikasi Bakteri Termofilik dari Sumber Mata Air Panas Songgoriti Setelah Dua Hari Inkubasi”. Jurnal Teknik Pomits. vol. 1 no. 1 (2012).

Marina, Iche Dewi. "Isolasi Bakteri dan Uji Aktivitas Kitinase Termofilik Kasar dari Sumber Air Panas Tinggi Raja, Sumalungun Sumatera Utara". Tesis. Medan: USU, 2008.

Muharni, et,all. "Isolasi dan Identifikasi Bakteri Penghasil Kitinase dari Sumber Air Panas Danau Ranau Sumatera Selatan". Laporan Hasil Penelitian. Lampung: Fak. MIPA Universitas Lampung, 2010.

Mushoffa. "Isolasi dan Identifikasi Bakteri Selulolitik dari Feses Kambing". Skripsi (Malang: Fak. Sains dan Teknologi UIN Maulana Malik Ibrahim, 2012).

Pakpahan, Rosliana. "Isolasi Bakteri dan Uji Aktivitas Protoase Termofilik dari Sumber Air Panas Sipohon Tapanuli Utara Sumatera Utara", Tesis, (Medan : USU 2009), h. 5.

Risdianto, Didik dan Soetoyo. "Survei Terpadu Geologi, Geokimia Dan Geofisika Daerah Panas Bumi Massepe, Kabupaten Sidenreng Rappang Sulawesi Selatan". Laporan Hasil Penelitian (Makassar: Pusat Sumber Daya Geologi, 2008), h. 3.

Safrilya, Evrin Vanadianingrum. "Isolasi dan Karakterisasi Bakteri Penghasil Enzim Xilanase dari Cairan Rumen Kambing, Domba dan Sumber Air Panas di Cipanas". Skripsi (Bogor: Fak. Peternakan IPB, 2008), h. 7.

Sari, Ratna Hadi, et.all. Dasar-Dasar Mikrobiologi. Jakarta: UI-Press, 2007

Suriawiria, Unus. Mikrobiologi Air. Bandung: P.T. ALUMNI, 2008.Wesley A. Volk dan Margaret F. Wheeler. Mikrobiologi Dasar (Basic Mikrobiology), terj. Markham. Jakarta: Erlangga, 1993.

Suyati. "Identifikasi Dan Uji Antibiotik Bakteri Gram-Negatif Pada Sampel Urin Penderita Infeksi Saluran Kemih (Isk)”. Skripsi (Manokwari: Fak. MIPA, 2010), h. 17-20.

W. Bibiana, Lay. Analisis Mikroba. Jakarta: PT RajaGrafindo Persada. 1994. 
Raifah Mahmudah, Maswati

Baharuddin, \& Sappewali

Identifikasi isolate bakteri termofilik dari sumber air panas Lejja,

Kabupaten Soppeng

"Karakterisasi dan Identifikasi Bakteri Termofilik Amilolitik dengan Menggunakan Metode Fenotifik dan Metode Molekuler Gen Parsial 16S rRNa", Skripsi (Bandung: UPI, 2010), h. 2 . 